\section{Daily Evapotranspiration of Guzmania 'Irene' and Vriesea 'Carly' Bromeliads Produced in a Shaded Greenhouse}

\author{
Richard C. Beeson, Jr. and Jianjun Chen ${ }^{1}$ \\ Mid-Florida Research and Education Center and Department of \\ Environmental Horticulture, Institute of Food and Agriculture Sciences, \\ University of Florida, 2725 S. Binion Road, Apopka, FL 32703
}

Additional index words. actual evapotranspiration $\left(\mathrm{ET}_{\mathrm{A}}\right)$, bromeliad daily water use, daily water requirements, ornamental foliage plants, water need index (WNI)

\begin{abstract}
Bromeliads are important ornamental foliage plants, but until now, their daily water use during production was unknown. Using a canopy closure model developed for container-grown woody ornamental plants, in this study we investigated actual evapotranspiration ( $\left.\mathbf{E T}_{\mathrm{A}}\right)$ of Guzmania 'Irene' and Vriesea 'Carly' from tissue-cultured liners grown in 15-cm containers to marketable sizes in a shaded greenhouse. The mean daily ET $_{\mathrm{A}}$ of Guzmania 'Irene' ranged from 4.02 to $66.35 \mathrm{~mL}$ per plant, and the mean cumulative $\mathrm{ET}_{\mathrm{A}}$ was $16.66 \mathrm{~L}$ over a 95 -week production period. The mean daily $\mathrm{ET}_{\mathrm{A}}$ of Vriesea 'Carly' varied from 3.98 to $59.89 \mathrm{~mL}$ per plant, and the mean cumulative $\mathbf{E T}_{\mathrm{A}}$ was $15.52 \mathrm{~L}$ over the same production period as the Guzmania cultivar. The best-fit models for predicting daily $\mathbf{E T}_{\mathrm{A}}$ of the two bromeliads were developed, which had correlation coefficients $\left(r^{2}\right)$ of 0.79 for Guzmania 'Irene' and 0.68 for Vriesea 'Carly'. The success in the model of $E T_{A}$ for both bromeliads suggested that the canopy closure model was equally applicable to container-grown ornamental foliage plants produced in greenhouse conditions. The daily $\mathbf{E T}_{\mathrm{A}}$ and cumulative $E T_{\mathrm{A}}$ values represent researchbased information on water requirements, and, when applied, could improve irrigation practices in bromeliad production. This study also showed that roots per se of the two epiphytic bromeliads were able to absorb water and nutrients from a peat-based container substrate and support their complete life cycles.
\end{abstract}

The Bromeliaceae family comprises more than 3000 species across 58 genera that are largely native to tropical North and South America (Stevens, 2013). Their exotic appearance, graceful symmetry, and potential for year-round flowering make bromeliads among the most sought-after plants in the world (Henny and Chen, 2003). Among them, Aechmea Ruiz \& Pav., Cryptanthus Otto \& A. Dietr., Guzmania Ruiz \& Pav., Neoregelia L.B. Smith, Nidularium Lem., Tillandsia L., and Vriesea Lindl. are important ornamental foliage plants (Chen et al., 2005). It is estimated that nearly 60 million potted bromeliad plants are sold annually worldwide, of which $60 \%$ are Guzmania (Vanhoutte et al., 2016) and $15 \%$ are Vriesea cultivars (Vanhoutte et al., 2017).

Bromeliads have many unique characteristics, including epiphytism, water-absorbing leaf trichome, tank habit, and crassulacean acid metabolism (CAM), that enable them to survive under various harsh environmental

Received for publication 29 June 2018. Accepted for publication 2 Oct. 2018.

This project was supported in part by the Southwest Florida Water Management District. We thank Russell Caldwell for assistance in completion of this study and Caroline Roper for editing the manuscript.

${ }^{1}$ Corresponding author. E-mail: jjchen@ufl.edu. conditions (Leroy et al., 2016). More than $60 \%$ of bromeliads are epiphytes (Zotz, 2013). Epiphytic bromeliads have two life forms: tank bromeliads, whose leaves spiral and arrange to form a rosette cup or tank where they accumulate water and organic debris, and atmospheric bromeliads, whose leaves are narrow and do not serve as a reservoir (Benzing, 2000; Givnish et al., 2007). Leaf hair or foliar trichomes are specialized for water and nutrient absorption and are called absorptive trichomes (Zotz, 2013).

Both Guzmania and Vriesea are tank bromeliads and considered to be $\mathrm{C}_{3}$ plants (Pierce et al., 2001) with exception of some Guzmania that are facultative CAM species (Freschi et al., 2010). Their growth and development under protected culture may be different from their wild habitats. Commercially, they are produced in soilless substrates under climate-controlled greenhouses and supplied with ample water and nutrients. A recent study showed that roots of two cultivars of Vriesea are able to absorb much more water than trichome in commercial production conditions (Vanhoutte et al., 2017). Roots of Vriesea have been shown to possess root hairs, a vascular system, and an endodermis (Proenca and Sajo, 2008; Reinert and Mereilles, 1993), implying that the roots are capable of taking up water and nutrients. Gas exchange and plant growth of Guzmania lingulata (L.) Mez. fertigated through roots were comparable with those fertigated through tank (Silva et al., 2017).

With current commercial production practices, irrigation of bromeliads has been primarily based on growers' experience. A common problem with the production of container-grown plants has been overirrigation, resulting in not only poor aeration in container substrates but also nutrient leaching (Chen et al., 2001). This holds true in bromeliad production, where daily water requirements have not been quantified for any bromeliad species. To increase irrigation efficiency, Beeson (2004) proposed a canopy closure model for estimating $\mathrm{ET}_{\mathrm{A}}$ of container-grown woody ornamental plants as a basis for precision irrigation. Based on the relationships of $\mathrm{ET}_{\mathrm{A}}$, potential evapotranspiration $\left(\mathrm{ET}_{\mathrm{O}}\right)$, and projected canopy area (PCA) of a given species, a water need index (WNI) or plant factor (Kjelgren et al., 2016) is calculated, which is a function of canopy closure of a group of plants, relating individual plant $\mathrm{ET}_{\mathrm{A}}$ to plant size and canopy ventilation and radiation (Beeson, 2005). Daily $\mathrm{ET}_{\mathrm{O}}$ was calculated using the Campbell Scientific version of the Penmen-Monteith equation, whereas $\mathrm{ET}_{\mathrm{A}}$ was determined by an autonomous weighing lysimeter system (Beeson, 2011). The model has been used to quantify daily $\mathrm{ET}_{\mathrm{A}}$ of several woody ornamental plants including Ligustrum japonicum (Beeson, 2004), Viburnum odoratissimum (Beeson, 2010a, 2010b), Rhaphiolepis indica (Beeson, 2012), as well as foliage plants Asplenium nidus L. and Chamaedorea elegans Mart. (Chen and Beeson, 2013), and Calathea G. Mey. 'Silhouette' and Stromanthe sanguinea Sond. (Beeson and Chen, 2018). Irrigation of container-grown plants based on daily water use has been documented to reduce nursery runoff volume and nutrient load without reducing plant growth (Hagen et al., 2014; Pershey et al., 2015).

The objectives of this study were to determine $\mathrm{ET}_{\mathrm{A}}$ of Guzmania and Vriesea from tissue-cultured liners grown in $15-\mathrm{cm}$ containers to marketable sizes in a shaded greenhouse and to develop models to predict daily $\mathrm{ET}_{\mathrm{A}}$ rates. It is anticipated that such effort could provide research-based information for improving irrigation efficiency during bromeliad production.

\section{Materials and Methods}

Experimental location. This study was carried out in an $80 \%$ shaded greenhouse at the University of Florida's Mid-Florida Research and Education Center (MREC) in Apopka. A Florida Automated Weather Network (FAWN, https://fawn.ifas.ufl.edu/) station at MREC is about $46 \mathrm{~m}$ east of the shaded greenhouse. The station provided readings of air temperatures at three elevations $(0.6,1.8$, and $9.1 \mathrm{~m})$, soil temperature, wet bulb temperature, dew point, relative humidity, rainfall, and wind speed every 15 min daily as well as daily evapotranspiration outside the greenhouse. The outside $\mathrm{ET}_{\mathrm{O}}$ was calculated based on the Campbell 
Scientific Program (Campbell Scientific, 1991) which uses the full ASCE PenmanMonteith equation (Jensen et al., 1990).

Data collection system. The miniature weighing lysimeter system described by Beeson (2011) was used in this study. The system was composed of a control/data collection board connected to mini lysimeters. The control board consisted of a CR10X data logger, SDM-AM16-32 multiplexer, and SDM-CD16AC relay control module (Campbell Scientific Inc., Logan, UT) for receiving and storing data from the mini-lysimeters. Each mini-lysimeter included a load cell (SSM-50-AJ; Interface Inc., Scottsdale, AZ) suspended from a miniature tripod with a plant support suspended from the load cell. All load cells were calibrated with a sevenpoint curve using known masses. The data logger program recorded the mass of each lysimeter every half hour and stored it for later retrieval. At midnight, the program determined that day's $\mathrm{ET}_{\mathrm{A}}$ for each lysimeter as the difference between mass at $0500 \mathrm{HR}$ and midnight. There was no transpiration between midnight and $0500 \mathrm{HR}$. $\mathrm{ET}_{\mathrm{A}}$ was calculated by hand using the half hour lysimeter data as described by Beeson (2006) when needed.

Plants were watered through a drip irrigation system to allow a $10 \%$ leachate fraction. Water was supplied through selffashioned rings of pressure compensated drip tubing (Netafilm USA, Fresno, CA). As supplied, pressure compensating emitters were arranged in $30.5-\mathrm{cm}$ intervals along the length of the tubing. Lengths containing four emitters were cut and rolled to form two loops, which were joined by a T-barb. These fit snugly into the top of each container. Loops were connected to a $19-\mathrm{mm}$ polyethylene tubing using equal lengths of $6 \mathrm{~mm}$ tubing. The Christensen's Coefficients of Uniformity were determined for 15 loops from plants on each bench. The mean coefficient was 0.94 and ranged from 0.93 to 0.96 . Typical application rates per bench were $187 \mathrm{~mL} \cdot \mathrm{min}^{-1}$

Bromeliad plant production. Tissue cultured liners of Guzmania 'Irene' and Vriesea 'Carly' were transplanted singly into $15-\mathrm{cm}$ containers $(1.6 \mathrm{~L})$ filled with a peat-based substrate composed of $60 \%$ Canadian peat, $20 \%$ vermiculite, and $20 \%$ perlite by volume. Plants were fertilized by top dressing $5 \mathrm{~g}$ of a controlled-released fertilizer (CRF) (Osmocote $19 \mathrm{~N}-2.18 \mathrm{P}-7.47 \mathrm{~K}, 8-9$ months; The Scotts Co., Marysville, $\mathrm{OH}$ ) per container 3 weeks after potting. The same amount of the CRF was applied 42 weeks later. The experiment was arranged as a completely randomized block design with four replications. In each block, 15 plants of a species were arranged in five rows with three plants per row in an offset pattern and spacing of 30 $\mathrm{cm}$ between pots. The center plant was placed in a suspension-weighing lysimeter, and the four closest plants to the lysimeter plant were designated as the interior plants for repeated canopy measurements. Plants were grown in a shaded greenhouse under a maximum photosynthetic active radiation of $200 \mu \mathrm{mol} \cdot \mathrm{m}^{-2} \cdot \mathrm{s}^{-1}$

Air temperature, relative humidity, wind, and solar radiation required for calculation of reference evapotranspiration $\left(\mathrm{ET}_{\mathrm{O}}\right)$ were collected with an automated Weatherhawk weather station (Campbell Scientific, Inc.) inside the middle of the greenhouse $50 \mathrm{~cm}$ above the lysimeter tripods. The algorithm used to calculate $\mathrm{ET}_{\mathrm{O}}$ was the same as that used in more robust outside weather stations based on Campbell Scientific equipment (Campbell Scientific, 1991). This was installed to evaluate the hypothesis that although the use of the Penman-Monteith equation inside a greenhouse violates the basis of Penman-Monteith, the thermodynamic associations of heat and random movement of water molecules within leaves and plant canopies would still mimic that of leaves outside nonetheless.

Data collection. Data collection was initiated within a week after transplanting. Canopy measurements of widest width, width perpendicular to the widest width, and average height were recorded every 3 weeks on the lysimeter plants and adjacent four plants for each replication. The two widths of each plant were multiplied to estimate the two-dimensional PCA (i.e., canopy footprint). When PCA was multiplied by the average height, canopy volume, or growth index, was estimated (Henny et al., 2009), assuming the three-dimensional canopy resembled a rectangular box. Plant water-use efficiency was calculated as total dry matter produced $(\mathrm{g})$ by actual amount of water used $\left(\mathrm{ET}_{\mathrm{A}}\right)$ (Stanhill, 1987).

Modeling plant water use. $\mathrm{ET}_{\mathrm{A}}, \mathrm{ET}_{\mathrm{O}}$, and PCA were used to evaluate the suitability of the percent canopy closure $(\% \mathrm{CC})$ model (Beeson, 2004, 2010a, 2010b) for determining water use of greenhouse-grown bromeliads. To summarize, $\% \mathrm{CC}$ at each measurement was calculated by adding half the PCA of each of the four border plants to the PCA of the lysimeter plant and dividing the sum by allocated bench space for each plant $\left(929 \mathrm{~cm}^{2}\right.$ in this study). Because plants
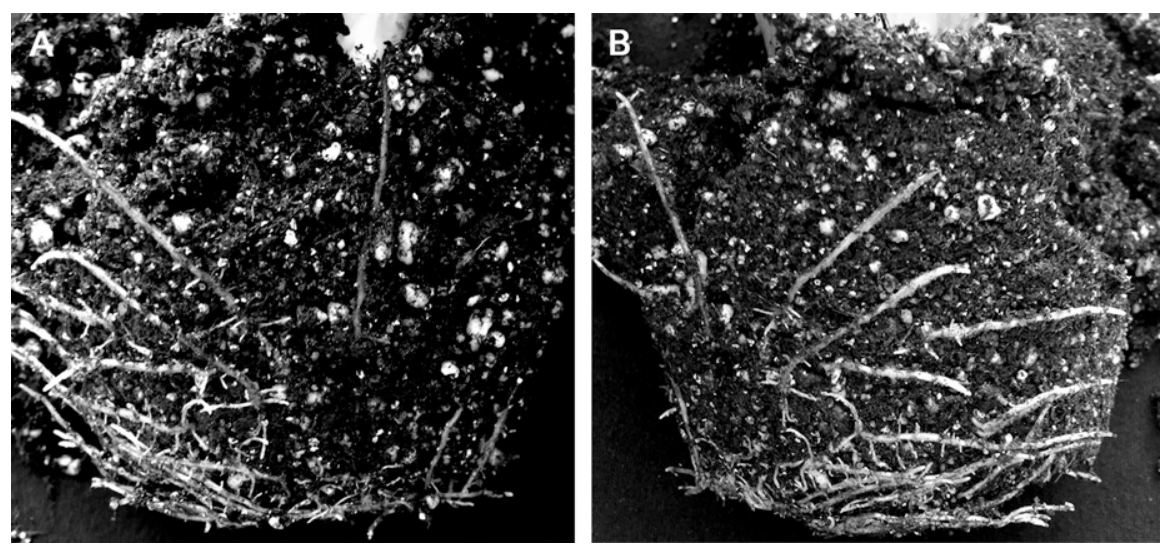

Fig. 1. Roots of Guzmania 'Irene' (A) and Vriesea 'Carly' (B) 3 months after growing in 15-cm containers filled with a peat-based substrate. Both plants had well-developed roots when watered through drip irrigation to the substrate not into the tank or cup. were not respaced, canopies could become overlapped with plant growth. Thus, overlapping could result in calculation of $\% \mathrm{CC}$ greater than $100 \%$. For each lysimeter plant, $\mathrm{ET}_{\mathrm{A}}$ was recorded for $7 \mathrm{~d}$ and converted to a depth by dividing with its average PCA $\left(\mathrm{cm}^{2}\right) \cdot \mathrm{ET}_{\mathrm{A}}(\mathrm{cm})$ was then normalized by dividing with its corresponding $\mathrm{ET}_{\mathrm{O}}(\mathrm{cm})$ each day, and then averaged over the $7 \mathrm{~d}$ to calculate WNI using the equation of [WNI = $\left.\left(\mathrm{ET}_{\mathrm{A}} / \mathrm{PCA}\right) / \mathrm{ET}_{\mathrm{O}}\right]$ for each lysimeter plant at each measurement date. Calculated WNI values of the four lysimeter replicates for each date were plotted against their corresponding \%CC values. The plot was fitted to a three-parameter exponential decay curve using SigmaPlot (Version 10; SPSS Inc., Chicago, IL). An equation for the nonlinear line was derived using a three-level inverse polynomial equation (Version 10; SPSS Inc.).

\section{Results}

Reference evapotranspiration. The $\mathrm{ET}_{\mathrm{O}}$ $\left(\mathrm{ET}_{\mathrm{O}-\mathrm{GH}}\right)$ values in the shaded greenhouse were $\approx 12 \%$ of that outside the shaded greenhouse as measured by the FAWN station. Solar radiation in the shaded greenhouse was around $15 \%$ that of outdoor conditions, and relative humidity was normally higher inside the greenhouse. Although there was no measurable wind, air movement occurred during most afternoons from early spring until late fall due to operation of evaporative cooling fans. Temperatures in the shaded greenhouse were also more moderate than outside conditions, with minimums set at $18.3{ }^{\circ} \mathrm{C}$ for heating and $32.2{ }^{\circ} \mathrm{C}$ for evaporative cooling. $\mathrm{ET}_{\mathrm{O}}$ was highest in April and May (days 90 to 150), declined the rest of the period with the onset of summer rains, then shorter days. In Central Florida, April and May tend to have the highest vapor pressure deficits (VPD) due to mostly clear skies and low humidifies resulting from the near absence of rainfall. Evaporative cooling during this period often is insufficient to maintain low VPD. 
Root growth. To assess root growth of two bromeliad species watered through drip irrigation, plants were pulled from containers 3 months after potting. Both species had wellestablished roots systems. Many roots had penetrated the substrate, with white, healthy roots appearing in the interface of container wall and substrate, and some had root hairs (Fig. 1).

Shoot growth. Guzmania 'Irene' was potted in Nov. 2006 and harvested in Sept. 2008,
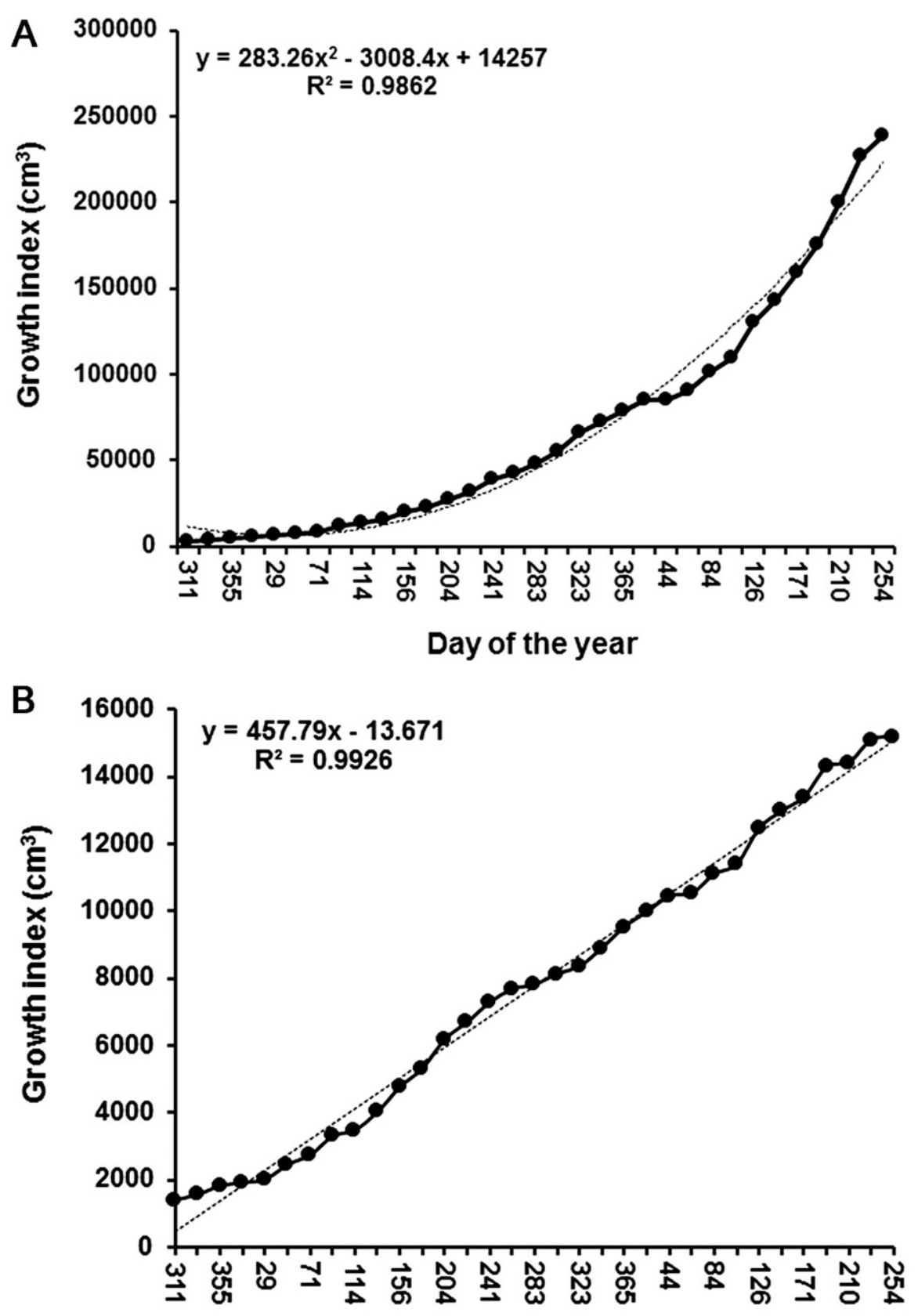

\section{Day of the year}

Fig. 2. Growth indices ( $\left.\mathrm{cm}^{3}\right)$ of Guzmania 'Irene' (A) and Vriesea 'Carly' (B) grown in 15-cm containers from tissue-cultured liners to marketable sizes. The equations are based on the best-fit dash line.

when they had reached a size suitable for commercial marketing. Leaves were glossy green with a mean length of $40 \mathrm{~cm}$. Canopy heights and widths of Guzmania 'Irene' increased linearly (data not shown), but its growth index increased polynomially (Fig. 2A). Guzmania 'Irene' produced 10 to 15 fuchsia-magenta bracts, which are modified leaves. At harvest, mean canopy height and width were $45.6 \mathrm{~cm}$ and $71.9 \mathrm{~cm}$, respectively. It had a mean of 33.3 leaves and a total leaf area of $4,067.4 \mathrm{~cm}^{2}$. Shoot and root fresh weights were $176.2 \mathrm{~g}$ and $12.7 \mathrm{~g}$, and corresponding dry weights were $29.1 \mathrm{~g}$ and $2.4 \mathrm{~g}$, respectively. Guzmania 'Irene' had a water use efficiency of 1.9 (Table 1).

Vriesea 'Carly' was potted concurrently with Guzmania 'Irene' in Nov. 2006 and harvested in Sept. 2008 when a marketable size was attained. 'Carly' has green and stiff leaves with a mean length of $16 \mathrm{~cm}$. Canopy heights of Vriesea 'Carly' increased linearly, and widths increased polynomially (data not shown). Growth index increased linearly (Fig. 2B). Vriesea 'Carly' has yellow and red flower spikes. Mean canopy height and width at the time of harvest were $22 \mathrm{~cm}$ and $26.3 \mathrm{~cm}$, respectively. 'Carly' produced 28.9 leaves with a total leaf area of $1583.5 \mathrm{~cm}^{2}$. Shoot and root fresh weights were $48.7 \mathrm{~g}$ and $9.6 \mathrm{~g}$; shoot and root dry weights were $8.5 \mathrm{~g}$ and $2.0 \mathrm{~g}$, respectively. Water use efficiency of Vriesea 'Carly' was 0.7 (Table 1).

Actual evapotranspiration. The mean cumulative $\mathrm{ET}_{\mathrm{A}}$ for Guzmania 'Irene' was 16.66 L per plant during the entire production period. At the beginning of the experiment, mean $\mathrm{ET}_{\mathrm{A}}$ ranged from 5.91 to $17.74 \mathrm{~mL}$ per plant per day (Fig. 3A). Beginning in Feb. 2007, mean $\mathrm{ET}_{\mathrm{A}}$ increased more than 2-fold over the next $50 \mathrm{~d}$, ranging from 23.66 to $35.49 \mathrm{~mL}$ per day. During the summer months of 2007, mean $\mathrm{ET}_{\mathrm{A}}$ averaged around $29.57 \mathrm{~mL}$ per day but ranged from 6.21 to $51.37 \mathrm{~mL}$ per day during this period. The variability in $\mathrm{ET}_{\mathrm{A}}$ is likely due to highly fluctuation in cloud cover during the summer rainy season. Mean $\mathrm{ET}_{\mathrm{A}}$ began declining in August (day 300) to reach a low in Dec. 2007, comparable with that of the first December in 2006. Mean $\mathrm{ET}_{\mathrm{A}}$ again began increasing from late January 2008 to the summer of 2008. Mean $\mathrm{ET}_{\mathrm{A}}$ was quite variable during this period, ranging from 4.02 to $66.35 \mathrm{~mL}$ per day. The decline in Aug. 2008 mirrored that measured the previous year.

The mean cumulative $\mathrm{ET}_{\mathrm{A}}$ value was 15.52 L for Vriesea 'Carly'. Initial daily $\mathrm{ET}_{\mathrm{A}}$ for individual plants ranged from $7.64 \mathrm{~mL}$ to $32.93 \mathrm{~mL}$ (Fig. 3B). This declined quickly to 4.48 to $11.83 \mathrm{~mL}$ per day by the middle of

Table 1. Plant growth measurements at harvest by species. Plants were harvested when they had reached common commercial canopy sizes along with flowers. ${ }^{2}$

\begin{tabular}{|c|c|c|c|c|c|c|c|}
\hline Species & $\begin{array}{c}\text { Mean } \\
\text { leaf } \\
\text { no. }\end{array}$ & $\begin{array}{c}\text { Leaf } \\
\text { area } \\
\left(\mathrm{cm}^{2}\right)\end{array}$ & $\begin{array}{c}\text { Shoot } \\
\text { fresh wt } \\
(\mathrm{g})\end{array}$ & $\begin{array}{c}\text { Root } \\
\text { fresh wt } \\
\text { (g) }\end{array}$ & $\begin{array}{c}\text { Shoot } \\
\text { dry wt } \\
\text { (g) }\end{array}$ & $\begin{array}{c}\text { Root } \\
\text { dry wt } \\
\text { (g) }\end{array}$ & $\begin{array}{c}\text { Water use } \\
\text { efficiency } \\
(\mathrm{g} / \mathrm{L})\end{array}$ \\
\hline Guzmania 'Irene' & $33.3 \pm 1.2$ & $4,067.4 \pm 268.8$ & $176.2 \pm 6.9$ & $12.7 \pm 2.7$ & $29.1 \pm 2.2$ & $2.4 \pm 0.4$ & 1.9 \\
\hline
\end{tabular}

${ }^{\mathrm{z}}$ Values represent the means plus SE with four replications except for water use efficiency.

${ }^{\mathrm{y}}$ Water use efficiency is the ratio of total dry weight (g) to total amount of water used (L). 
December (day 45). Beginning in Feb. 2007, mean $\mathrm{ET}_{\mathrm{A}}$ increased 2.5-fold over the next $50 \mathrm{~d}$ to a range from 23.66 to $35.49 \mathrm{~mL}$ per day, similar to that shown for Guzmania 'Irene' (Fig. 3A). During the summer months of 2007, mean $\mathrm{ET}_{\mathrm{A}}$ averaged around $29.57 \mathrm{~mL}$ per day but ranged from 7.5 to $59.89 \mathrm{~mL}$ per day during this period. Mean $\mathrm{ET}_{\mathrm{A}}$ began declining in August (day 300) to reach a low in Dec. 2007, comparable with that of the first
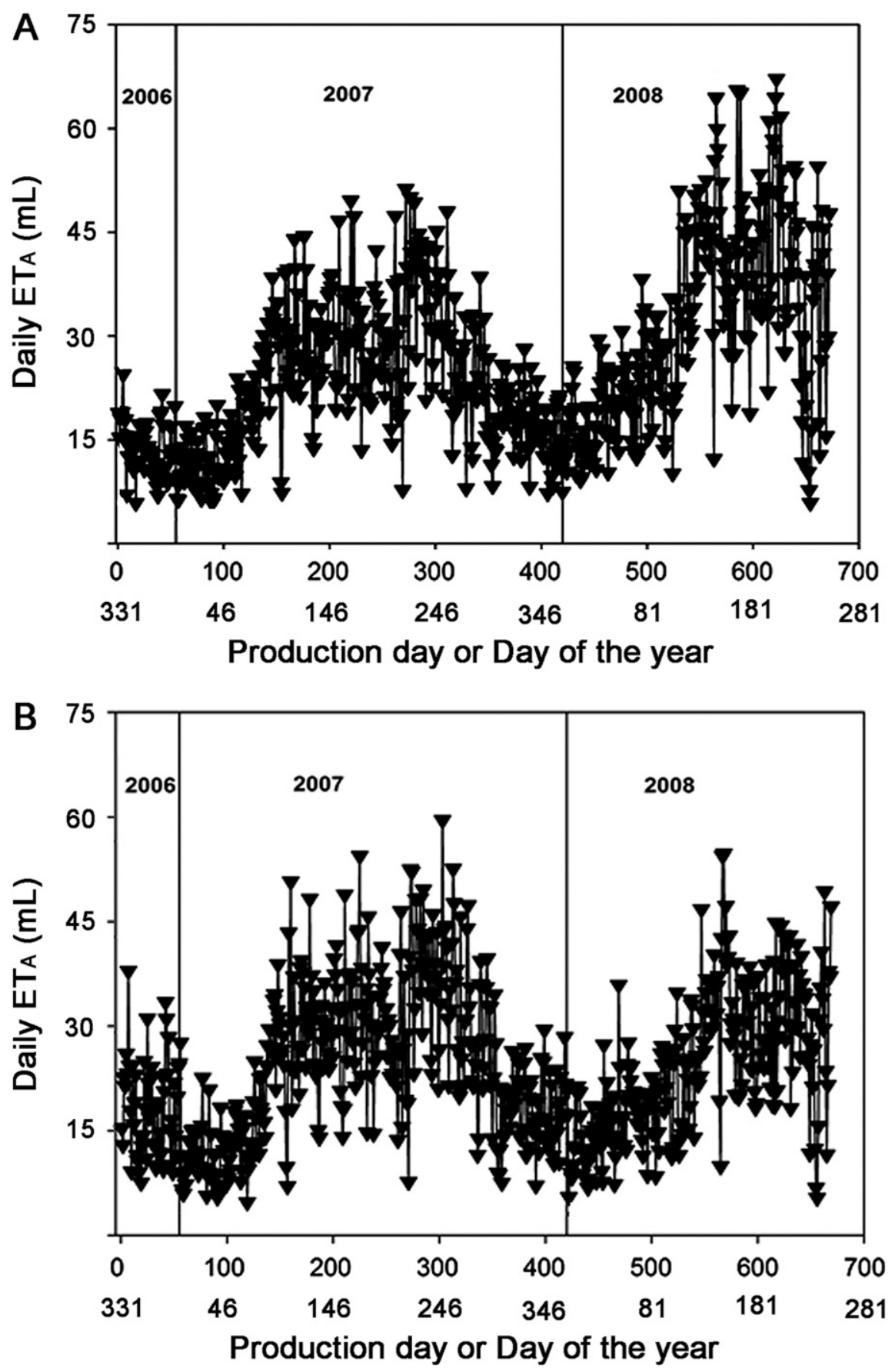

Fig. 3. Mean daily actual evapotranspiration $\left(\mathrm{ET}_{\mathrm{A}}\right)$ of Guzmania 'Irene' $(\mathbf{A})$ and Vriesea 'Carly' $(\mathbf{B})$ grown in $15-\mathrm{cm}$ containers during production from tissue-cultured liners to marketable sizes. Each point is the mean of four plant replicates. The horizontal axis is marked with days after transplanting and calendar day.

December and 'Irene'. Mean $\mathrm{ET}_{\mathrm{A}}$ again began increasing in late January 2008 to a median mean $\mathrm{ET}_{\mathrm{A}}$ of $32.53 \mathrm{~mL}$ per day during the summer of 2008. Mean $\mathrm{ET}_{\mathrm{A}}$ was variable during this period, ranging from $3.98 \mathrm{~mL}$ to $47.32 \mathrm{~mL}$ per day. The sharp decline in Aug. 2008 also mirrored that measured the previous year.

Data analysis and modeling. Application of the \%CC model (Beeson, 2010a) was successful for both bromeliads with the best fit model presented in Table 2 . The significance of $r^{2}$ values ( 0.79 and 0.68 for Guzmania and Vriesea, respectively) for both equations suggested that the two species exhibited strong relationships between WNI and the level of canopy closure. As derived, equations predict the water use of individual plants. If means could have been derived from these individual plant measurements, such that the relationships were derived for populations of plants, the $r^{2}$ would have been higher and predictions of overall crop water use would be more certain.

For both Guzmania 'Irene' and Vriesea 'Carly', the WNI coefficients declined with increasing plant growth, indicated by the increase in \%CC (Fig. 4A and B). In brief, this decline in WNI was due to increases in canopy boundary layer resistance as plant foliage expanded and filled in the gaps between containers. At near 100\% canopy closure, transpiration of all but the upper leaves become decoupled from the air above the canopy, resulting in $40 \%$ deceases in whole plant transpiration outdoors (Beeson, 2010a). Conversely random removal of $\approx 33 \%$ plant canopy coverage had been shown to increase individual plant transpiration by $40 \%$ (Beeson, 2010a).

\section{Discussion}

Agricultural use of fresh water has been under rigorous scrutiny due to irrigation, accounting for up to $62 \%$ of freshwater use, including $68 \%$ of groundwater and $29 \%$ of surface water withdrawals in the United States (Kenny et al., 2009). Containergrown plant production is an extensive water user within the realm of agriculture (Beeson, 2011; Chen et al., 2001, 2003). Plants are grown in confined volumes filled with artificial substrates, which are watered frequently to avoid drought stress. Irrigation frequency and quantity, however, is largely based on grower's intuition or experience. As a result, plants are often overirrigated (Belayneh et al., 2013). Overirrigation not only reduces substrate aeration but also results in excess runoff and leaching of nutrients, primarily nitrogen $(\mathrm{N})$ and phosphorus $(\mathrm{P})$. Movement of $\mathrm{N}$ and $\mathrm{P}$ in waterways could potentially

Table 2. Best-fit models for predicting daily $\mathrm{ET}_{\mathrm{A}}$ values of Guzmania 'Irene' and Vriesea 'Carly' grown in 15-cm containers from tissue-cultured liners to marketable sizes.

\begin{tabular}{llc}
\hline Species & Model equation & $r^{2}$ \\
\hline Guzmania 'Irene' & $\mathrm{WNI}=0.110+0.695 / \% \mathrm{CC}-0.132 / \% \mathrm{CC}^{2}-0.051 / \% \mathrm{CC}^{3}$ & 0.79 \\
Vriesea 'Carly' & $\mathrm{WNI}=-3.222+5.207 / \% \mathrm{CC}-1.685 / \% \mathrm{CC}^{2}-0.182 / \% \mathrm{CC}^{3}$ & 0.68 \\
\hline
\end{tabular}

$\mathrm{ET}_{\mathrm{A}}=$ actual evapotranspiration; $r^{2}=$ correlation coefficient; $\mathrm{WNI}=$ water need index; $\% \mathrm{CC}=$ percent canopy closure. 

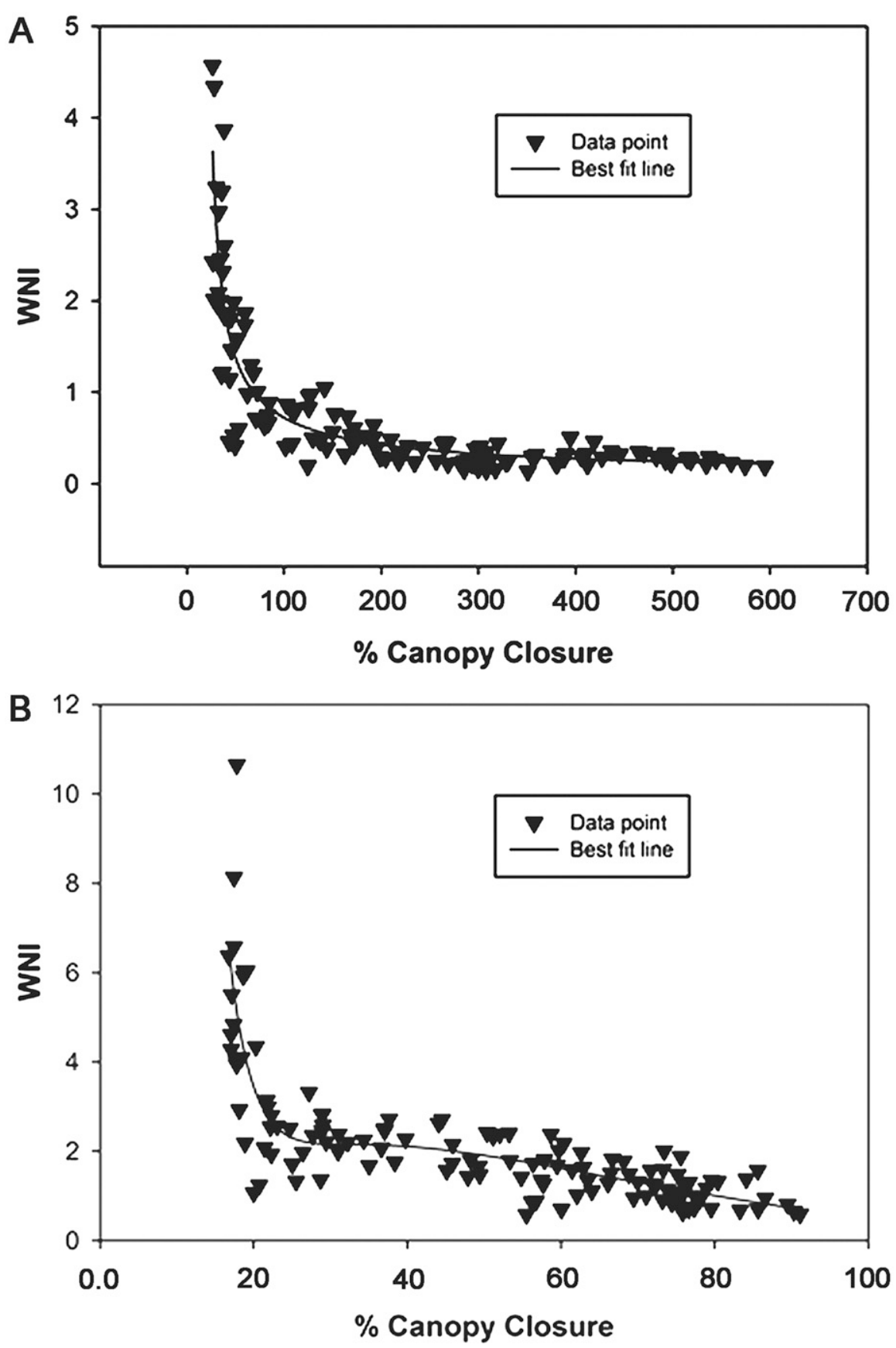

Fig. 4. Inverse polynomial relationship between percent canopy closure $(\% \mathrm{CC})$ and the water need index (WNI) for Guzmania 'Irene' (A) and Vriesea 'Carly' (B). Data points are four plant replicates, and equation for the best-fit line presents in Table 2 .

contaminate ground and/or surface water (Chen et al., 2001). Thus, irrigation based on plant growth requirements is increasingly important for sustainable production of container-grown ornamental plants.

The present study shows that plants differ almost daily in water requirements. $\mathrm{ET}_{\mathrm{A}}$ values varied from 4.02 to $66.35 \mathrm{~mL}$ for Guzmania 'Irene' and $3.98 \mathrm{~mL}$ to $59.89 \mathrm{~mL}$ for Vriesea 'Carly' over a 95-week production period. The variation, however, does exhibit an identical pattern regardless of plant species: a slight increase in $\mathrm{ET}_{\mathrm{A}}$ in Nov. 2006 that was due to plant establishment after transplanting and then a decrease in the might have much high transpiration than a compact single spike of Vriesea.

The cumulative $\mathrm{ET}_{\mathrm{A}}$ values of Guzmania 'Irene' (16.66 L) and Vriesea 'Carly' (15.52 L) were comparable with those our previous studied Asplenium nidus $(7.95 \mathrm{~L})$ and Chamaedorea elegans (6.43 L) (Chen and Beeson, 2013) as well as Calathea G. Mey. 'Silhouette' (4.84 L) and Stromanthe sanguinea Sond. (6.81 L) (Beeson and Chen, 2018) if considering the production time. The production time for the two bromeliads was $665 \mathrm{~d}$ compared with $294 \mathrm{~d}$ for both $A$. nidus and $C$. elegans, $224 \mathrm{~d}$ for Calathea, and $231 \mathrm{~d}$ for Stromanthe. Commercial production of Guzmania and Vriesea in 15-cm containers usually takes less than $250 \mathrm{~d}$, during which ethylene is used to force flowering. In our study, we did not use ethylene; plants flowered naturally, which resulted in a prolonged production time. Another note is that Guzmania 'Irene' and Vriesea 'Carly' varied greatly in leaf areas, shoot, and root dry weights (Table 1), but their cumulative $\mathrm{ET}_{\mathrm{A}}$ only differed by $1.1 \mathrm{~L}$. This could be due in part to the faster growth rate of Guzmania 'Irene', as illustrated in Fig. 1, and higher water use efficiency (1.9) (Table 1), whereas Vriesea 'Carly' growth was slower with a water use efficiency of 0.7 . Another reason is that leaves of Guzmania 'Irene' were much longer than Vriesea 'Carly' ( $40 \mathrm{~cm}$ vs. $16 \mathrm{~cm}$ ). Guzmania 'Irene' reached canopy closure much quicker (Fig. 4A) than Vriesea 'Carly' (Fig. 4B). The continuous growth of Guzmania 'Irene' caused increased overlapping of leaves, resulting reduced transpiration and the demand for water, as shown in Fig. 4A. In contrast, the appearance of 10 to 15 bracts after May 2008 increased transpiration; thus, $\mathrm{ET}_{\mathrm{A}}$ of Guzmania 'Irene' was higher compared with Vriesea 'Carly' during the same period. Nevertheless, the application of the canopy closure model was successful for both bromeliads, and the best-fit model is presented in Table 2. The $r^{2}$ values for the WNI as a function of $\% \mathrm{CC}$ were high, 0.79 for Guzmania 'Irene' and 0.68 for Vriesea 'Carly'. Results from this study, along with the previous reports (Beeson and Chen, 2018; Chen and Beeson, 2013) suggest that the canopy closure model and WNI developed for woody ornamental plants are suitable for modeling daily water requirements of container-grown foliage plants in greenhouse conditions. As far as we know, this is the first report on the daily water use of bromeliads. This study provides important information for commercial production of both Guzmania and Vriesea and probably other bromeliads.

This study also showed that roots of both Guzmania 'Irene' and Vriesea 'Carly' were functional. Since plants were fertilized by topdressing a CRF on substrate and watered via drip irrigation and not through tank, water and nutrients must have be taken up through roots. As shown in Fig. 1, both Guzmania 'Irene' and Vriesea 'Carly' indeed had welldeveloped root systems. Interestingly, root systems of many tank bromeliads, such as Tillandsioideae species in general, often are classified as nonabsorptive and mainly serving 
to anchor these plants (Benzing, 2000), whereas foliar trichomes are essential for water and nutrient absorption from the tank solution (Inselsbacher et al., 2007). Our results showed that epiphytic bromeliads, when cultivated in a substrate, emitted new roots that are functional. Vanhoutte et al. (2017) also showed that roots of Vriesea are important for water and nutrient absorption. The importance of trichomes in water and nutrient absorption could be due to the evolutionary adaptation of epiphytic bromeliads in the wild. The ability of cultivated bromeliad roots to take up water and nutrients may suggest great physiological plasticity of epiphytic bromeliads in adaptation to commercial cultivation. Breeding of bromeliads for ornamental purposes also may select plant roots not only for anchoring plants but also for effective absorption of water and nutrient for commercial production.

In conclusion, the canopy closure model and WNI developed for woody ornamental plants are suitable for modeling daily water requirements of container-grown foliage plants in greenhouse conditions. The daily $\mathrm{ET}_{\mathrm{A}}$ established for Guzmania and Vriesea could be used as references for developing optimal irrigation recommendations for commercial bromeliad production. Development of WNI models for other groups of bromeliads would like conserve water and reduce nutrient leaching. In addition, Guzmania and Vriesea develop functional roots and can be irrigated via roots or roots and tanks in commercial bromeliad production.

\section{Literature Cited}

Beeson, R.C., Jr. 2004. Modeling actual evapotranspiration of Ligustrum japonicum from rooted cuttings to commercially marketable plants in 12 liter black polyethylene containers. Acta Hort. 664:71-77.

Beeson, R.C., Jr. 2005. Modeling irrigation requirements for landscape ornamentals. HortTechnology 15:18-22.

Beeson, R.C., Jr. 2006. Relationship of plant growth and actual evapotranspiration to irrigation frequency based on managed allowable deficits for container nursery stock. J. Amer. Soc. Hort. Sci. 131:140-148.

Beeson, R.C., Jr. 2010a. Response of evapotranspiration of Viburnum odoratissimum to canopy closure and the implications for water conservation during production and in landscapes. HortScience 45:359-364.

Beeson, R.C., Jr. 2010b. Modeling actual evapotranspiration of Viburnum odoratissimum during production from rooted cuttings to market size plants in 11.4-L containers. HortScience 45:1260-1264.

Beeson, R.C., Jr. 2011. Suspension lysimeter systems for quantifying water use and modulating water stress for crops grown in organic substrates. Agr. Water Mgt. 98:967-976.

Beeson, R.C., Jr. 2012. Development of a simple reference evapotranspiration model for irrigation of woody ornamentals. HortScience 47:264-268.

Beeson, R.C., Jr., and J. Chen. 2018. Quantification of daily water requirements of contain-grown Calathea and Stromanthe produced in a shaded greenhouse. Water 10:1194.

Belayneh, B.E., J.D. Lea-Cox, and E. Lichtenberg. 2013. Costs and benefits of implementing sensor-controlled irrigation in a commercial pot-in-pot container nursery. HortTechnology 23:760-769.

Benzing, D. 2000. Bromeliaceae: Profile of an Adaptive Radiation. Cambridge University Press, Cambridge, UK.

Campbell Scientific. 1991. Application Note 4-D. Campbell Scientific Ltd., Logan, UT.

Chen, J. and R.J. Beeson, Jr. 2013. Actual evapotranspiration of Asplenium nidus and Chamaedorea elegans during production from liners to marketable plants. Acta Hort. 990:339-344.

Chen, J., R.C. Beeson, Jr., T.H. Yeager, R.H. Stamps, and L.A. Felter. 2003. Evaluation of captured rainwater and irrigation runoff for greenhouse foliage and bedding plant production. HortScience 38:228-233.

Chen, J., Y. Huang, and R.D. Caldwell. 2001. Best management practices for minimizing nitrate leaching from container-grown nurseries. TheScientificWorld 1(S2):96-102.

Chen, J., D.B. McConnell, D.L. Norman, and R.J. Henny. 2005. The foliage plant industry. Hort. Rev. 31:47-112.

Freschi, L., C.A. Takahashi, C.A. Cambuia, T.R. Semprebom, A.B. Cruz, P.T. Mioto, L.M. Versieux, A. Calvente, S.R. Latansio-Aidar, M.P.M. Aidar, and H. Mercier. 2010. Specific leaf areas of the tank bromeliad Guzmania monostachia perform distinct functions in response to water shortage. J. Plant Physiol. 167:526-533.

Givnish, T.J., K.C. Millam, P.E. Berry, and K.J. Systsma. 2007. Phylogeny, adaptive radiation, and historical biogeography of Bromeliaceae inferred from $n d h F$ sequence data. Aliso 23:3-26.

Hagen, E., S. Mambuthiri, A. Fulcher, and R. Geneve. 2014. Comparing substrate moisturebased daily water use and on-demand irrigation regimes for oakleaf hydrangea grown in two container sizes. Scientia Hort. 179:132-139.

Henny, R.J. and J. Chen. 2003. Cultivar development of ornamental foliage plants. Plant Breed. Rev. 23:245-290.

Henny, R.J., J.R. Holm, J. Chen, and M. Scheiber. 2009. In vitro induction of tetraploids in
Dieffenbachia x 'Star Bright M-1' by colchicine. HortScience 44:646-650.

Inselsbacher, E., C.A. Cambui, A. Richter, C.F. Stange, H. Mercier, and W. Wanek. 2007. Microbial activities and foliar uptake of nitrogen in the epiphytic bromeliad Vriesea gigantean. New Phytol. 175:311-320.

Jensen, M.E., R.D. Burman, and R.G. Allen. 1990 Evapotranspiration and irrigation water requirements. 28 Aug. 2018. <http://agris.fao.org/agrissearch/search.do? recordID=US19910106366>.

Kenny, J.F., N.L. Barber, S.S. Hutson, K.S. Linsey, J.K. Lovelace, and M.A. Maupin. 2009. Estimated water use in the United States in 2005. U.S. Dept. Interior. U.S. Geol. Surv. Circ. 1344.

Kjelgren, R., R.C. Beeson, Jr., D.R. Pittenger, and D.T. Montague. 2016. Simplified landscape irrigation demand estimation: Slide rules. Appl. Eng. Agr. 32:363-378.

Leroy, C., J.F. Carrias, R. Céréghino, and B. Corbara. 2016. The contribution of microorganisms and metazoans to mineral nutrition in bromeliads. J. Plant Ecol. 9:241-255.

Pershey, N.A., B.N. Cregg, J.A. Andresen, and R.T. Fernandez. 2015. Irrigating based on daily water use reduces nursery runoff volume and nutrient load without reducing growth of four conifers. HortScience 50:1553-1561.

Pierce, S., K. Maxwell, H. Griffiths, and K. Winter. 2001. Hydrophobic trichome layers and epicuticular wax powders in Bromeliaceae. Amer. J. Bot. 88:1371-1389.

Proenca, S.L. and M.G. Sajo. 2008. Rhizome and root anatomy of 14 species of Bromeliaceae. Rodriguésia 59:113-128.

Reinert, F. and S. Mereilles. 1993. Water acquisition strategy shifts in the heterophylous saxicolous bromeliad Vriesea geniculata (Wawra) Wawra. Selbyana 14:80-88.

Silva, K.G., E.A. da Silva, M.L. Ferreira, S. Kanashiro, P.B. de Camargo, and A.R. Tavares. 2017. Gas exchange and chlorophyll a fluorescence parameters of ornamental bromeliads. Ornament. Hort. 23:400-406.

Stanhill, G. 1987. Water use efficiency. Adv. Agron. 39:53-85.

Stevens, P. 2013. Angiosperm Phylogeny Website Version 13. 20 June 2018. <http://www.mobot. org/MOBOT/research/APweb/>.

Vanhoutte, B., J. Ceusters, and M. Proft. 2016. The tubing phenomenon in commercial cultivation of Guzmania: Morphology, physiology and anatomy. Scientia Hort. 205:112118.

Vanhoutte, B., L. Schenkels, J. Ceusters, and M.P. De Proft. 2017. Water and nutrient uptake in Vriesea cultivars: Trichomes vs. roots. Environ. Expt. Bot. 136:21-30.

Zotz, G. 2013. The systematic distribution of vascular epiphytes - a critical update. Bot. J. Linn. Soc. 171:453-481. 